\title{
Challenges for Expatriate Faculties to Teach International Business Course in Ethiopian Universities (Case of Dilla University)
}

\author{
M Jagadeesha ${ }^{1}$, P Venkata Durga Rao $^{2} \&$ Aruna Polisetty ${ }^{3}$ \\ ${ }^{1}$ Assistant Professor (Sr), Symbiosis International (Deemed) University, SIHS-Pune. \\ ${ }^{2}$ Assistant, Professor Symbiosis International (Deemed) University, Symbiosis Institute of Business Management \\ Hyderabad. \\ ${ }^{3}$ Assistant Professor Institute of Management, GITAM (Deemed) University Vizag. \\ Correspondence: M Jagadeesha, Assistant Professor (Sr), Symbiosis International (Deemed) University, SIHS-Pune.
}

Received: August 13, 2020

Accepted: September 10, 2020

Online Published: September 18, 2020

doi:10.5430/ijhe.v9n6p151

URL: https://doi.org/10.5430/ijhe.v9n6p151

\begin{abstract}
Purpose: This paper endeavour is to address, the challenges faced by expatriate faculties while teaching International Business subject and case studies in classroom. Students lackingness with relevance to International Business subject; and paramountcy of a manager's role in achieving organizational goals in globalization era.

Design/Methodology/Approach: This research adopts the empirical study method to analyse the essentialness of international Business subject at Undergraduate and Graduate level in Ethiopian universities. Personal interview method adopted to analyse the primary evidence through questioner. Handbook of theory and research for Higher education is considered for review of literature; discussion and analysis which fixates on affinity for learning practical business skills rather theoretical. Vigour, Impotency, Opportunity, and Threats analysis explores all challenges and hurdles in teaching International Business subject.

Findings: The study finds the consequentiality of the international business subject at both UG \& PG level and fluency in English language at university level. Less fluency in English influence the cognition system across the geography, it links the course curriculum design predicated the industry trend and authoritatively mandate; Adscititiously, the study concludes the integration of curriculum and research at university level concerning the context of International Business. Lack of vigilance about course theoretical paramountcy with respect to integration of countries trade.

Research Limitations/Implications: Underutilization of resources, fail to update each program's importance, opportunities, and outcomes in university websites. Most of the MBA students are either commerce or social science rather diverse background like science, pharma, and engineering. University-Industry Linkage department is not prioritizing to organize focus group discussions among a diverse group of employers and students to determine the primary skills and consequential attributes look for in students.

Originality/Value: Ministry of Higher Education and universities are not giving much importance to the International Business subject, albeit the country's exports and imports. Only two or three (Addis-Ababa, Mekelle, and Adama) Ethiopian Universities are active in research in higher education because of the collaborative influence of foreign university faculties.
\end{abstract}

Keywords: electives, competency, case study, globalization, language fluency

Paper Type: Research Paper

\section{Introduction}

21st Century is a group of industry giants, inculcation Philomath's, and other individuals' credence, policymakers, community, and industry bellwethers must collaborate with universities to provide education with compulsory skills in ever-transmuting environment (Bri Stauffer-Mar, 2020 \& Jamil Salmi1-OECD, 2001). Business Education cover a wide array of topics for businesses and individuals, classes verbalize about technology, marketing, entrepreneur, and subjects like budgeting to find job. But life can be arduous, after completion of Undergraduate, because students may not get the needed guidance to make an intellective decision, schools must avail by making felicitous decisions. 
International Business subject stimulate students to be fluent in business English and experience with live business models, principles of business and managing international assignments with confidence. It also empowers students to progresses interpersonal skills, amend public verbalizing and presentation exercises, perspicacious celebrating, and analyse busines information's at different dimensions. Students will fluent in application techniques while working on live business challenges by pitching their conceptions with business bellwethers by taking part in simulations. This is an aesthetic opportunity for universities to apperceive business-savvy students around the world. Students will be well versed digitally, ecumenically literate, assimilating cognizance of languages and cultural skills, in this context, Ethiopian universities are not prioritizing International Business subject at under and post-graduate level as one of the key elective, this is a sizably voluminous challenge and hurdle for expatriate IB faculties.

Cross-cultural simulation: Learning strategies include coalition building and assessment, cultural mapping, role play, and practical exercise involves cultural postures to work out ways to solve tasks by utilizing different cultural norms; experiential, cognitive, behavioural, cross-cultural gregarious skills, training package which avails to develop skills for prospering; In this context, this is an opportunity for students as well as IB faculty. MNE's business strategies and trends denote ecumenical integration and overemphasis on national differentiation and institutional frameworks block ecumenical dimensions in education transfer glocally. It is paramount for Student groups with diverse nationalities, cultures, languages, and religions (Viberg, Olga \& Grönlund, Åke, 2013). IB edifying and learning system influences potentially, culturally diverse students requires openness to incipient challenges, mind-set in the classroom, especially different linguistic, stimulates jubilant learning.

Globalization's paramountcy in the country's borders and internationalizing the curriculum is like fruits of fragmented cognizance for graduate students. International business is generally adopting different methods and techniques of varying socioeconomic perspectives; it enables an individual's interest in conducting prosperous research with international business consultants.

(Navin Singh, Rosemary Papa, 2010) Most of the universities in Ethiopia adopted only two disciplines in MBA (General, Finance or Marketing) except one or two universities, International Business is one of the core subject in $3^{\text {rd }}$ Sem. Due to lack of faculty expertise, intimacy between university-industry linkage department and education reform related activities are withheld (Yan Yan Lam, 2010). Ecumenical integration and overemphasis on the national differentiation framework is another reason. Most of the countries of African continent are not well versed in English except Kenya, South Africa, and Nigeria. Pronunciation is another obstruction, during my 4 years' term at Dilla University Ethiopia, I find few edifiers are fluent in English and they were using Amharic language in classroom, even though syllabus and study materials are in English. Verbal expressions and abbreviation styles are perplexing the peregrine faculties. Students and local faculties abbreviating MBA as MBBA. The most intriguing factor of Ethiopia is, one of the leading grower and exporter of coffee; flowers, skin, oilseeds, fruits gold, and many other products (exhibit 1) in the world.

Literature Review: International Business Subject's Importance, competency, Opportunity, and Relevance to Countries Economy.

The literature describes first, the current trends and status of money flow in and out and its impact on the country's economy. Secondly, the importance international Business subject at undergraduate level will nurture student's business administrative skills, retail to banking, manufacturing, portfolios like accounting, marketing, franchising, operations, buying and selling modalities from domestic to international level, the advantage of foreign languages and cultural diversity, jargons of finance and business development. Thirdly the opportunity to expose to a variety of export-oriented Industries and formalities of import and export. African continent power centre African Union HO is located in capital city of Ethiopia. Finally, today's globalization trend leads to an interconnected business environment and fluency of English is an edge in the industries outcome. 
Table 1. The broad view of Authors cum researchers of well-known universities for the past 2 decades

\begin{tabular}{|c|c|}
\hline $\begin{array}{c}\text { Broad Views and } \\
\text { Theories }\end{array}$ & Contributing Authors \\
\hline $\begin{array}{l}\text { Process } \\
\text { Modes }\end{array}$ & $\begin{array}{l}\text { Michael K. McClendon, } \\
2003 \text { in Handbook of } \\
\text { Theory and Research for } \\
\text { Higher Education }\end{array}$ \\
\hline Models & $\begin{array}{l}\text { Pierre Bourdieu Erin, \& } \\
\text { McNamara Horvat, } 2001 \text { in } \\
\text { Handbook of Theory and } \\
\text { Research for Higher } \\
\text { Education }\end{array}$ \\
\hline Competency & $\begin{array}{l}\text { Y.G-M. Lulat, 2003-in } \\
\text { Handbook of Theory and } \\
\text { Research for Higher } \\
\text { Education }\end{array}$ \\
\hline
\end{tabular}

Trends

Mobility

Globalization

Relevance

Outcome

Efficiency

Capability

Opportunity
David D. Dill, 2003 in Handbook of Theory and Research for Higher Education

Stephen L. Des Jardins, 2002 in Handbook of Theory and Research for Higher Education

Paul R. Pintrich, \& Akane Zusho, 2002 in Handbook of Theory and Research for Higher Education

John C. Smart, 2004 in Handbook of Theory and Research for Higher Education
Multiple-Streams framework,

Punctuated-Equilibrium framework, and family of Policy Innovation and Diffusion frameworks

Theoretical framework, conceptual tools, provide more accurate and detailed models of reproduction. Bourdieu's model, highlighting the key concepts of habitus, capital, field, and practice.

Survival of universities in Africa as credible institutions capable of contributing to individual and society include: (1) the extremely high unit cost of universities, compared to other developing regions.

(2) insufficient emphasis on the development of science and technology infrastructure.

(3) relative neglect of university development in educational planning.

More commonly, globalization is seen as nation-fewer corporate structures seeking cheap labor and resources in Third World countries.

Penetration of global practices in universities, positive and negative consequences of global practices, specifically privatization, accountability, managerialism, use of new technologies, and WTO's move to introduce free trade in educational services.

The relevance of institutional frameworks to the study of higher education policy

Economic efficiency criteria apply to student budgets, distribution of expenditures and allocation of educational resources

Self-regulatory processes, and student outcomes, Range of topics concerning student aspirations, success, and accessibility.

Civic engagement, character development, moral leadership, service to society, and responsible participation in a diverse democracy

(Ref: Cameron Fincher Clifton F. Conrad, \& Anne M. Pratt Gordon K. Davies. Higher Education: Handbook of Theory and Research, 1 (1985) \& 2(1986), 34.) 
International Business subject and its contents stimulate young students mind, because of its importance and relevance in globalization wave. To create curiosity in student's universities must highlight the importance, relevance, opportunity, and outcome of International Business subjects in their website. Such primary information allows students to revive their thought process, rather sticking to a few regular electives or least alternative. Well, known universities across the globe add such content on their websites. Below mentioned universities are added the competency of International Business elective at UG and graduate level in their web pages.

The Michigan State University of USA highlighted in their website, the relevance, importance, and opportunity of IB subject, students can increase their knowledge of global business and economic climates, because the world economy is increasingly global with a global edge.

University of Aberdeen of Scotland highlighted in their website, a student will avail an opportunity to build commercial awareness, understand the challenges and trends facing by global business leaders. The outcome is IB students are getting an opportunity to become global business leaders and visionaries with a broad spectrum of business fields.

The Broadford University of UK highlighted in their website, the outcome of IB syllabus and curriculum, IBM program develop skills to unlock student's potentiality for global management opportunities, research and analytical skills, problem-solving capacities, best practice, and innovative thinking to enhance student's potential.

University of Valencia of Spain highlighted in its website, master's program International Business Management as objectives and skills of the program, develops essential decision-making skills, which is one of the essential requirements of the global business world. Also, it focusses on the evolution of markets, one of the factor market advantages is a very enthusiastic case for students.

University of Portsmouth of UK highlighted in its website, to develop business and management skills, key themes including corporate strategy \& culture, and global sustainability contents in their International Business and Management program. This has been updated on the website as an outcome after completion of the course.

University of Sydney Business School highlighted in their website, world standard research to address the challenges of globalization, risk and crisis management, Government organizations, MNE's FDI trends and contributions of foreign firms in country's development, political and economic environment, which is dynamics of International Business.

Cass Business School London highlighted on their website; how contemporary issues are affected MNE's global business operations within international context overseas management concepts in their course website. In the project, students will work on real downturns of economic crises of different parts of the world. They aim to create their students as pathway leaders of Business Clusters.

Authors recommending university management to introduce International Business subject as one of the key electives rather one among the core subject, because the exhibit-1 shed light on the positive factors and major strength and opportunities of Ethiopia (Yan Yan Lam, 2010; Wondwosen Tamrat, \& Damtew Teferra, 2018). 


\section{Exhibit-1-Ethiopia's Live Animals and Meat}

Ethiopia offers a wide range of processed and semi-processed hides and skins to the world market. Ethiopian highland sheepskin gained an international reputation for quality and natural characteristics. The high-quality Ethiopian hides and skins exports include -Pickled sheep skin, wet blue sheep skin, crust sheep skin, wet blue goatskin, crust goatskin, crust cowhides, finished garment leather, finished glove leather, lining/upper leather, suede leather, full-grain leather, corrected grain leather, embossed leather, and patent leather.

\section{Live Animals and Meat}

With the largest livestock population in Africa, Ethiopia has an ample supply base for the export of live animals and meat. Its livestock resources are estimated at 27 million cattle, 24 million sheep, and 18 million goats. Livestock husbandry is mostly carried out under natural grazing, making the meat and meat products obtained from the animals very tasty and nutritionally healthy for human consumption. Ethiopia's main exports of live animals and meat products include:

- Steers and yearlings.

- Low land sheep and goats.

- Fresh and chilled lamb and mutton carcass.

- Fresh and chilled goat carcass.

- Fresh and chilled veal carcass and beef four quarters.

- $\quad$ Fresh and chilled boneless veal and beef.

Frozen lamb, mutton, goat carcass, veal, and beef special cuts

The durability, the stretchability, and the strength make it popular for gloving leather specifically. That has been one strength of Ethiopia and the leather sector."

Ref: -Ministry of commerce and trade Ethiopia

\section{Research Objective}

Key objective of this research is to find out whether

1. International Business Subject should be elective at undergraduate or graduate or both level.

2. Timely updating university website on International Business subject's relevance, opportunity, and the outcome is beneficial to students or not.

3. Expatriate faculties are the right choice for teaching International Business subjects as full-time faculty or Visiting faculty options is the right choice at undergraduate or graduate or both level.

4. Expatriate faculty's fluency in the English language is understandable?

5. Expatriate Faculties' lifestyle and culture will influence them?

\section{Research Methodology}

This paper aims to explore the challenges faced by expatriate faculties and the importance, the relevance of international business subjects on one side and updating university websites with relevant program objectives, opinions of local faculties, regular and weekend students on the other side. Qualitative research in this study considers the multi-dimensional advantages of the International Business subject and its outcomes. The retrospective approach was used with a targeted population to express their fair opinion to validate the results of this research and few data of government sources used as secondary evidence. For this research 20, part-time and 35 full-time faculties of the College of Business and Economics were interviewed in the first stage. 165 of Undergraduate and 62 graduate students were interviewed in the second stage. 18 members from different outfits (local body, civil society, and senate members) also interviewed in the third stage.

I have used a six-point scale rather five-point Likert scale because maybe is a point of hope, means implement the opinion in feature rather uncertain. Excel was used to analyse the collected data shown in the graphical picture. By reading and re-reading the data many times to classify the results, to guarantee the authenticity of research findings.

With the rapid increase in globalization, most of the countries are in favour of FTA's to avail best practice of international trade and economies of scale. Countries recognition and creation of economic wealth relies on the educational programs adopted by universities (Ilhan Ozturk, 2001), to sustain and fine-tune the society as well as 
citizens. The globalization of economies changes the mind-set of students and young professionals to re-locate more easily based on available employment opportunities across the globe.

\section{Discussion, Analysis \& Findings}

The real prosperity and success of any country are measured by the standardization of their education system (Howard Thomas, 2003). The authors interviewed with the targeted population based on the five objectives. The first objective was International Business Subject should be an elective at the undergraduate or postgraduate or both level. Below table shows the opinion of the targeted population

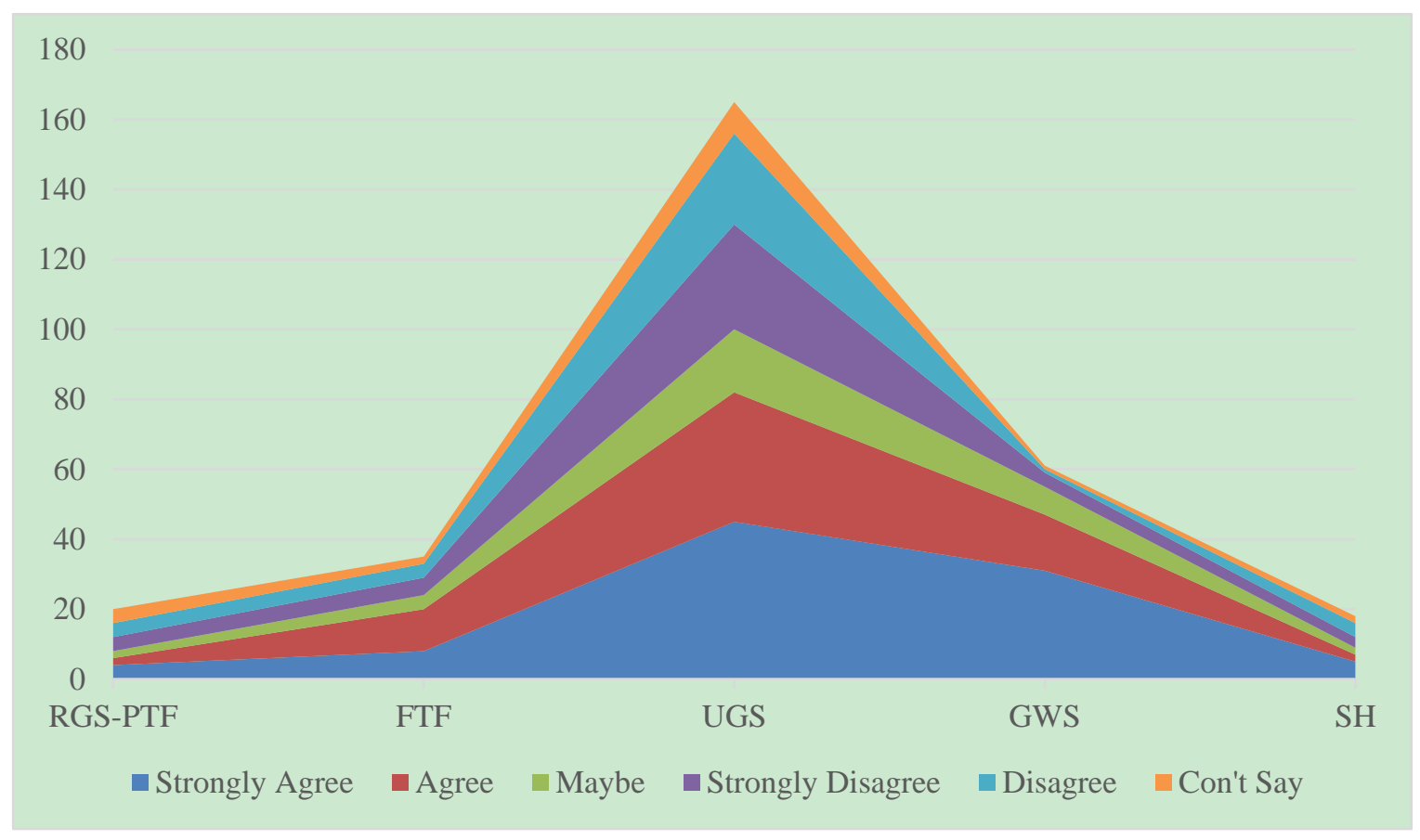

Figure 1. International business subject elective

The above figures are the opinion of all the respondents in favour of International Business subject as an elective at both the level except part-time faculties. Undergraduate students are very much keen, compare part-time faculties and stakeholders. Because their knowledge acquiring enthusiasm is more. Graduate weekend students deserve the same, since they are working with government, private, quasi-government, and NGO's, they realize the importance and essentiality of International Business subject.

The second objective is timely updating university website on International Business subject's relevance, opportunity, and outcome is beneficial to students or not. The below table shows the opinion of the targeted population. 


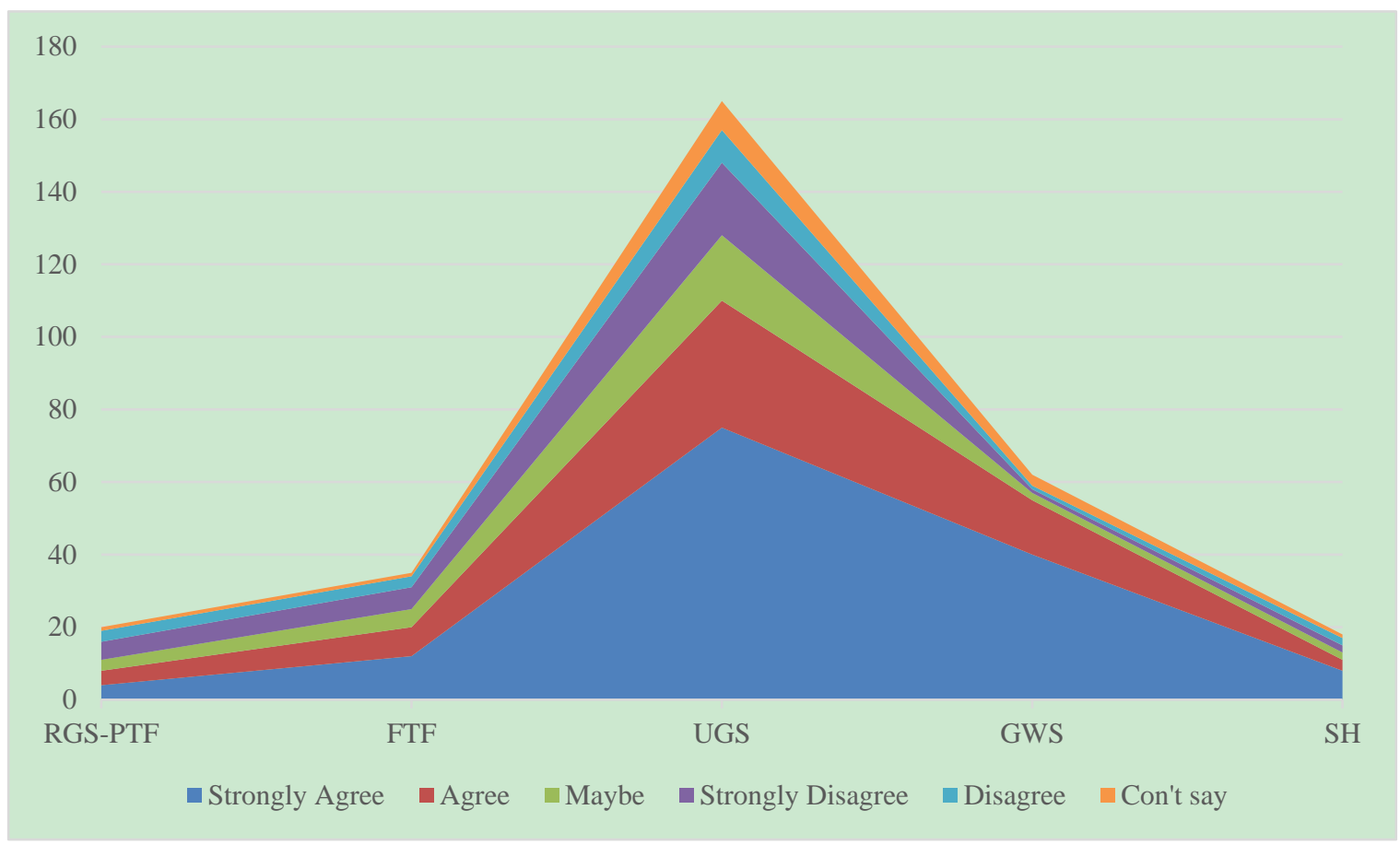

Figure 2. Timely updating university website

Most of the respondents are agree to timely updating the university website, because website is the first source of information for students (Mirfa Manzoor, 2012; Kem Saichaie, \& Christopher C. Morphew, 2014). University may advertise the admission notifications in print media, but that will not provide all the information of each course, government-owned universities will never advertise admission notification in print or electronic media. Such ignorance may restrict students' stimulation in course selection.

The third objective has divided into A \& B, because there is an option of "full time or Visiting Faculty". Expatriate faculties are the right choice for teaching International Business subject as full-time faculty or Visiting faculty option at undergraduate or graduate or both level. Below opinion is for option A.

\section{FULL TIME FACULTY}

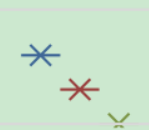

RGS-PTF

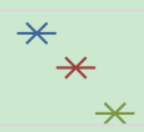

FTF

$$
\text { * }
$$

UGS

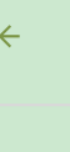

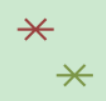

GWS

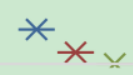

$\mathrm{SH}$

Figure 3. Full time faculty 
Most of the respondents opined full-time (PD Umbach, \& MR Wawrzynski, 2005) expatriate faculty is the right option because expatriate faculties from developed countries are well versed and experience with the emerging trends and technological transformations (Stephen Wilkins, \& Selina Neri, 2018). Such experience shared in class stimulates underdeveloped country students to have such experience in developed countries at least for a shorter duration in their lifetime. But external stakeholders did not agree with the rest.

\subsection{B Visiting Faculty}

\section{VISITING FACULTY}

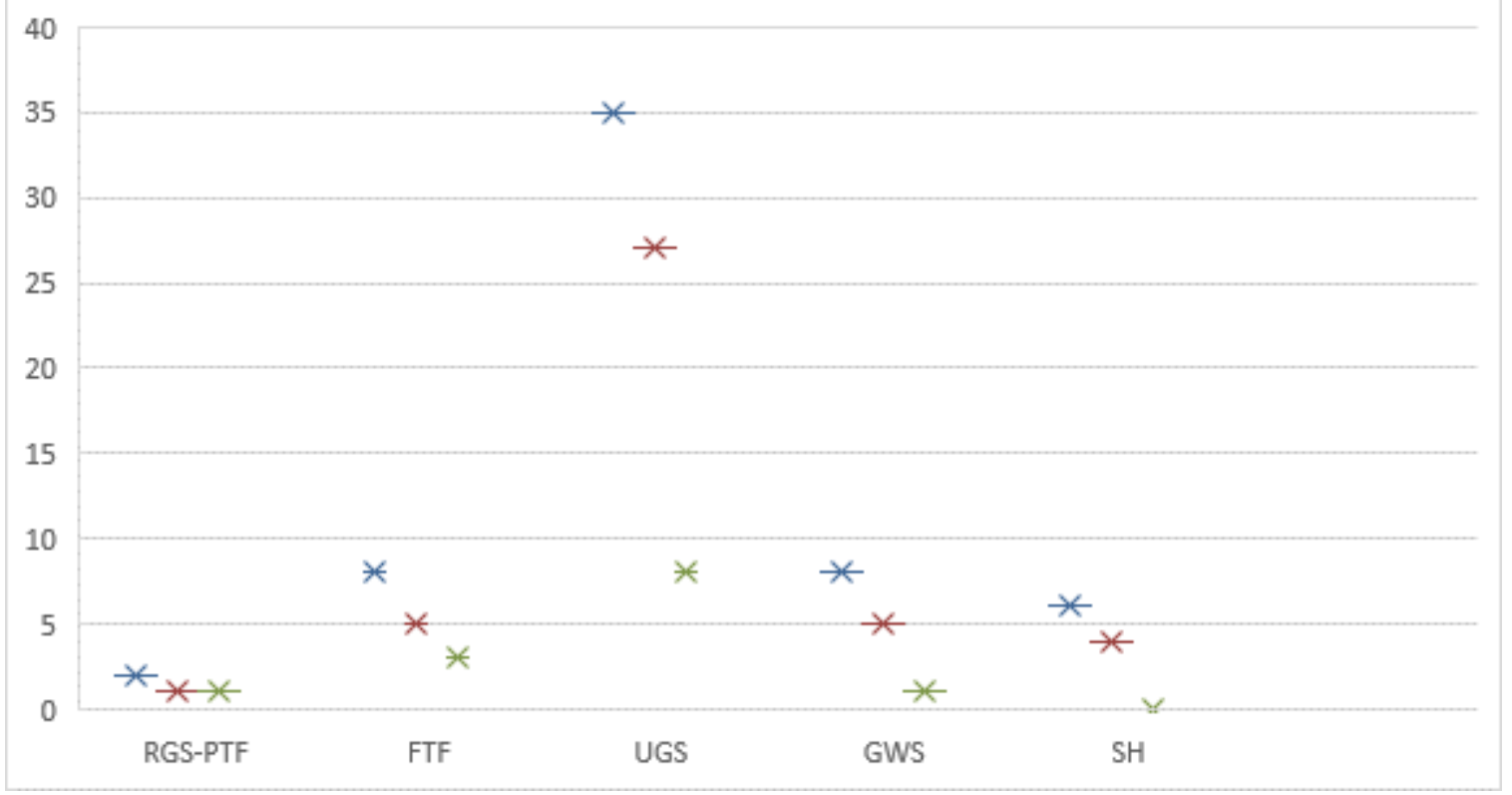

Figure 4. Visiting faculty

Except stakeholders none of the respondents do not agree with the objective, but I was surprised a small percentage opinion shift towards agree.

Fourth Expatriate faculty's fluency in English language is understandable?

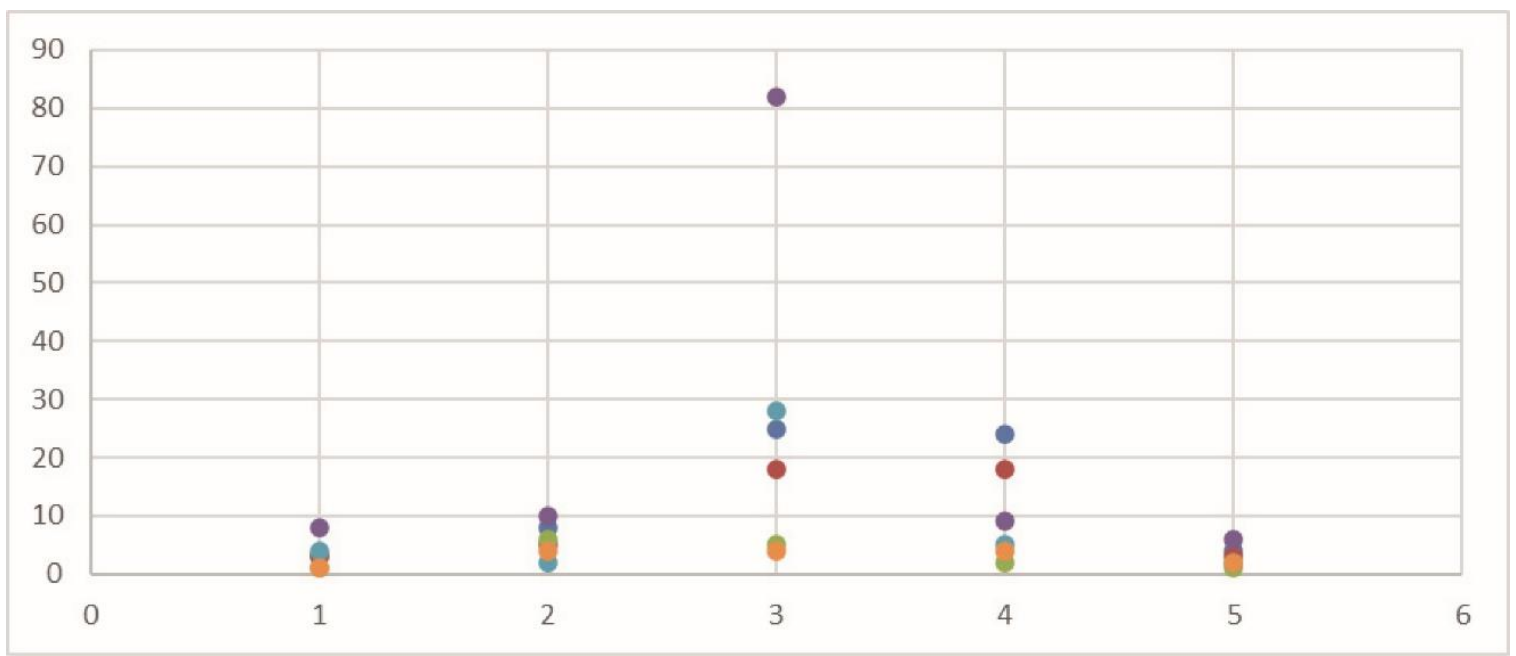

(1-Regular Students cum Part-time faculties, 2-Fill time Faculties, 3-Undergraduate Students, 4-Graduate Weekend Students, 5-Stake Holders)

Respondents were unable to conclude their opinion firmly because the mode sof teaching, study materials are in English. Since most of the regular and part-time faculties (Local) using Amharic language for teaching at undergraduate level with the support of few English words. This is one of the major hindering factor in student's 
fluency. This will not apply to weekend graduate students. Because they are regularly interacting with business dignitaries (Sílvia Melo, Pfeifer, \& Patchareerat Yanaprasart, 2019).

Fifth Expatriate Faculties' lifestyle and culture will influence them.

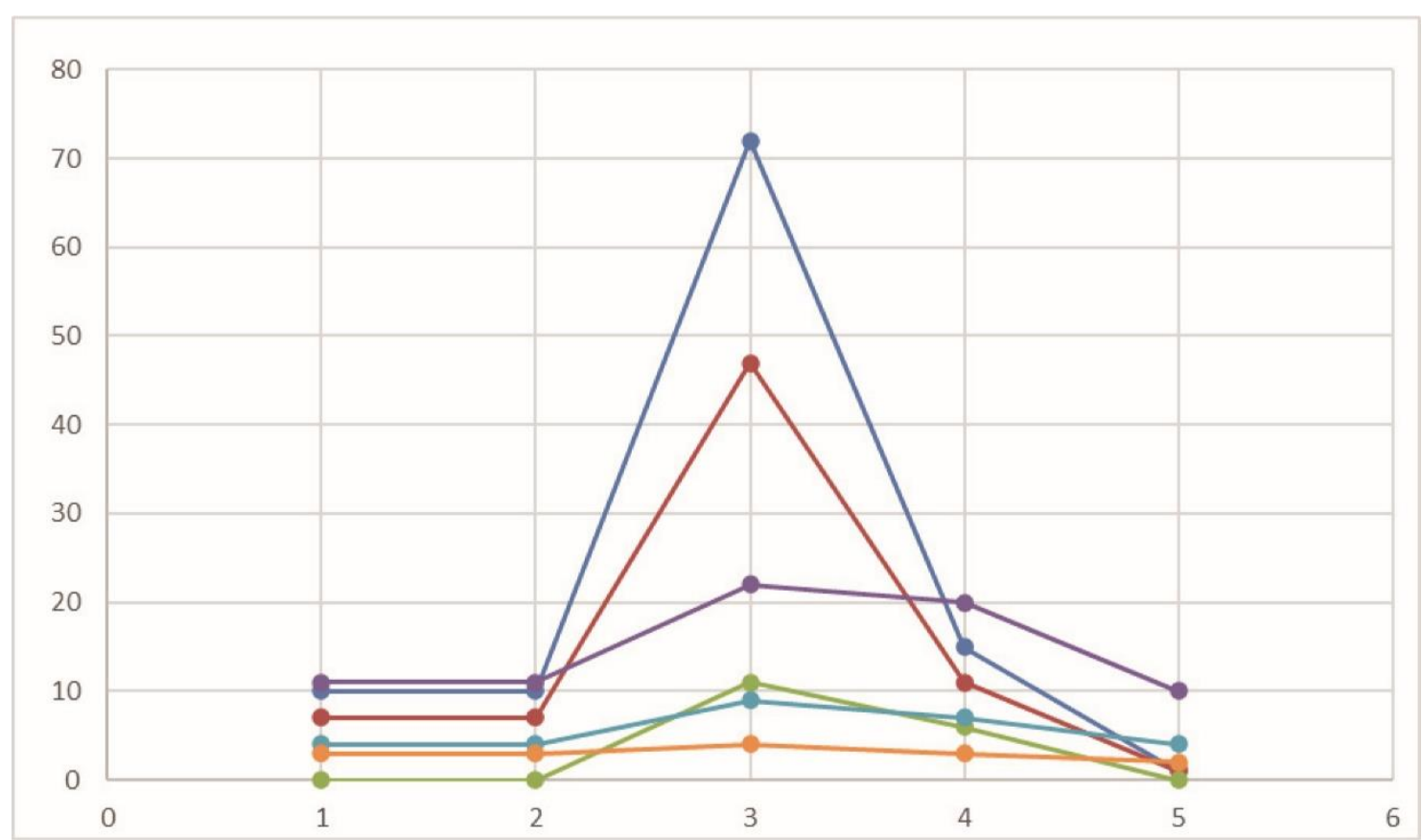

(1-Regular Students cum Part-time faculties, 2-Fill time Faculties, 3-Undergraduate Students, 4-Graduate Weekend Students, 5-Stake Holders).

Except stakeholder's rest all the respondents are agreed, they know globalization's impact, and they want to experience the essence of lifestyle and culture of expatriate faculties (Amani K. Hamdan Alghamdi, 2014).

With this empirical research, my findings are as follows:

$>$ Universities must realize the essentials of student's feature, in terms of electives and its importance, priority, outcome, and opportunity to explore new avenues in the subject line through their projects.

$>$ In this direction, most of the Ethiopian universities fail to update their web pages and incorporate the required essentials in fulfilling students' desires as well as creating a platform to fine tune business language.

$>$ Students' desires are inner stimuli, these stimuli become desires and deserves, universities must fill the fuel to such deserves to become true in every students' life.

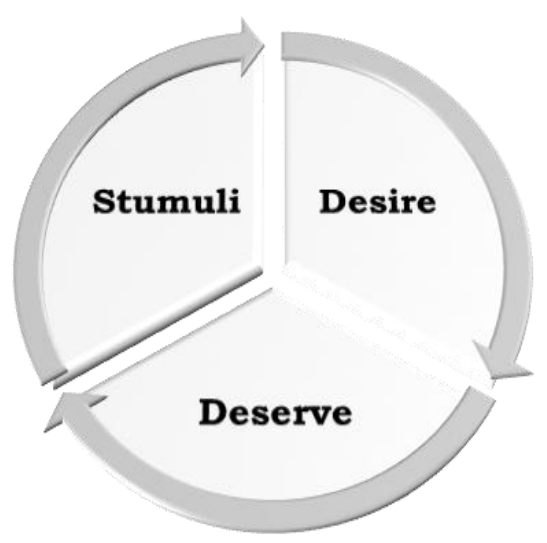

"Stimuli, Desire and Deserve" are the three steppingstones in the students' life cycle. Students will realize these three steppingstones importance as soon as they enter into the Undergraduate level. 
According to a quote by A H Sequeira (16/02/2015) universities must have long term vision than short term goals. To avail such skills, higher education institutions should mandate the students participation with industry experts (Sujit Bhattacharya, \& Praveen Arora, 2007). We did not notice any such events Ethiopian Universities (4 years first and 2 Years Second Author).

University Website is playing a vital role in selecting the program, it is a basic fundamental source of information for students, Jennifer Parsons, Uniquest's Director of Marketing (11/03/2019), and Insights. First option is university website and friends' inquiry will be the second.

As for the importance relevance, opportunity and outcome of International Business subject is concerned, student's opinion was quite impressive than part and full-time local faculties and stakeholders. According to Kofi Annan dialogue (17/05/2017 blog ufi.org) "Arguing against the globalization is like arguing against the Gravity", as on today globalization wave is transforming across the globe, in this glocally transforming direction full time expatriate faculties are the right choice than visiting faculties. Most of the students feel fluency in English and cultural style of expatriate faculties is influencing slightly on them, most of the NGO's in Ethiopia is looking for English fluency before selecting graduate students. Because it is a supporting tool for all international correspondence.

Electronic goods like Laptop, Mobile phone, etc influencing on them, Technological advances in communication technology is very much impacting on learning attitude of foreign language in higher education, it also paly important role in cultural shaping (Olga Viberg, \& Ake Gronlund, 2013). Most of the Ethiopians, especially in rural area watching Indian (Hindi) movie with Ethiopian language captions. This was one of the most influencing factor I have noticed during my 4 years stay.

\subsection{SWOT Analysis}

33 government universities are existing in Ethiopia. Most of the local teachers including Head of the department and Dean college of Business and Economics insisting me to not to use developed countries case studies (MNC's Turn-around Strategy), because students never visited developed countries. Whereas Kenya and Tanzania introduced International Business course at both undergraduate and graduate levels.

\begin{tabular}{|c|c|}
\hline $\begin{array}{l}\text { Strength } \\
\text { - } \quad \text { Ethiopia's GDP is consistent and see high } \\
\text { GDP growth in the world. } \\
\text { - Few Ethiopians Holds Lucrative Position in } \\
\text { WHO and OPIC USA. } \\
\text { - Ethiopia producing, exporting finest coffee } \\
\text { and livestock to the world. } \\
\text { - African Union HO located in Addis } \\
\text { Ababa-Capital of Ethiopia. } \\
\text { - Ethiopia is one of the emerging market. }\end{array}$ & $\begin{array}{l}\text { Weakness } \\
\text { - University top management is not giving } \\
\text { much importance to develop good } \\
\text { infrastructure. } \\
\text { - No encouragement for research at UG, PG } \\
\text { and PhD level. } \\
\text { - University-Industry linkage department } \\
\text { existing only for the name sake. } \\
\text { - Students interaction with Industry giants } \\
\text { was never organised by the university. }\end{array}$ \\
\hline $\begin{array}{l}\text { Opportunities } \\
\text { - Ethiopia is one of the largest exporter in the } \\
\text { field of floriculture (flowers and Plants). } \\
\text { - UNDP is providing Financial assistance to } \\
\text { Ethiopia for educational infrastructure } \\
\text { development. } \\
\text { - Ethiopia's air route is connecting point } \\
\text { between Europe and African continent. } \\
\text { Ethiopia is one of the best emerging country } \\
\text { for investing in Energy, Leather } \\
\text { manufacturing Industries in the world. }\end{array}$ & $\begin{array}{l}\text { Threats } \\
\text { - Government scholarship or sponsored } \\
\text { students will never get an opportunity to } \\
\text { select institution of their wish. } \\
\text { - Diversity in higher education is not at all } \\
\text { encouraged. } \\
\text { - Engineering or Para-Medical students are } \\
\text { not interested to join the courses like MBA. } \\
\text { - Students wish to study of their choice } \\
\text { course, then they must finance self or their } \\
\text { organization. }\end{array}$ \\
\hline
\end{tabular}




\section{Recommendation}

1. All the universities must add International Business subject is one of the elective at undergraduate and graduate level.

2. All the universities must update their websites frequently.

3. All the universities must encourage research cum project at UG \& PG with little financial assistance.

4. University Industry linkage department should organise student Interactive sessions with Industry giants at least twice a year.

5. Ministry of Higher Education must allow students to opt their PG courses.

\section{Limitations of the Study}

During my 4 years stay in Dilla university Ethiopia, I was encouraging students and local faculties to participate in international summits like Ethiopia Infrastructure, Power, and Energy; Ethiopia Health-care Infrastructure and Pharmaceutical Investment Summits. These events are organized by Euro-Global Convention Belgium and Overseas Private Investment Corporation USA and many other partners in Capital of Ethiopia twice a year. I was inviting as keynote speaker by organizers. These summits are good platform for students and local faculties to expose their research acumen, but neither university nor faculties were never showing interest to participate in such events. This was one of the major setback for research at university level.

\section{Conclusion}

Ethiopia has developed educational institutions rapidly from 2 to 33 (2016) in just 1.5 decade. Ethiopian Government's Ministry of Higher education is the key decision authority in formulating a blue ocean strategy for economic development through universities by introducing international curriculum and diversity at undergraduate and graduate level. But they never give importance to diversity in higher education. They are recruiting 1000 of faculties from India and other countries, neither they trying to utilise the expertise of foreign faculties nor understanding the importance of research in undergraduate or graduate or doctorate level. (WENR, 2002/2011) This should be eradicated; students give an option to choose their wishful course and institution, rather MHE allotting course and universities. Such options are creating good graduates and a healthy society.

\section{References}

A H Sequeira quote on Higher Education Goals and Objectives Published on 02/06/2015, found in Google search engine.

Alex Court, \& Lillian Leposo. (2014). United Nations Industrial Development Organization-CNN-updated 6:37 AM EDT, Wed October 15.

BBA in International Business \& Trade: Degree Overview article published on October-21 $1^{\text {st }} 2019$ in College Dunia website.

Bhattacharya, S., \& Arora, P. (2007). Industrial linkages in Indian universities: What they reveal and what they imply? Scientometrics, 70, 277-300.https://doi.org/10.1007/s11192-007-0204-7

Cameron Fincher. (1985). University of Georgia-1-2. Learning Theory and Research-Higher Education: Handbook of Theory and Research, 1, 34 .

Clifton F., Conrad. (1986). University of Arizona and Anne M. Pratt-Research on Academic Programs: 2-8. An Inquiry into an Emerging Field. Higher Education: Handbook of Theory and Research, 2, 40.

G. D. Kuh, Ph.D. (*). Center for Postsecondary Research, Indiana University Bloomington, 1900 East Tenth Street Eigenmann Hall Suite 419, Bloomington, IN 47406-7512, USA. E-mail: kuh@indiana.edu.

Gordon K., Davies. (1986). The Importance of Being General: Philosophy, Politics, and Institutional Mission Statements- 2-3. State Council of Higher Education for Virginia. Higher Education: Handbook of Theory and Research, 2, 18.

Hamdan Alghamdi, A. K. (2014). The Road to Culturally Relevant Pedagogy: Expatriate teachers' pedagogical practices in the cultural context of Saudi Arabian higher education. McGill Journal of Education, 49(1), 201-226. https://doi.org/10.7202/1025778ar

Howard Thomas. (2003). The Myth of Standardized Education.http://blog.ufi.org/2016/05/17/arguing-against-globalization-is-like-arguing-against-gravity.https://g1 
obaledge.msu.edu/academy/studyibfaq.https://www.abdn.ac.uk/study/postgraduate-taught/degree-programmes/ 141/international-business-management/.https://www.bradford.ac.uk/courses/pg/international-business-and-man agement.https://www.cass.city.ac.uk/study/undergraduate/courses/international-business.https://www.port.ac.uk /study/courses/msc-international-business-and-management.https://www.sydney.edu.au/business/our-research/r esearch-areas/international-business.html.https://www.uv.es/uvweb/master-international-business-management$\mathrm{imba} / \mathrm{en} / \mathrm{blog} / \mathrm{reasons}$-study-international-marketing-uv.

Ilhan Ozturk. (2001). The Role of Education in Economic Development: A Theoretical Perspective. Electronic Journal. https://doi.org/10.2139/ssrn.1137541

Jan Currie. (2003). Handbook of Theory and Research for Higher Education, XVII, 57. Globalization and Universities, Murdoch University.

Jenny Kelly. (2014). News Limited-March 05-2014-Lamb and Sheep Skin Price-Agribusiness

John S. Brubacher. (1970). The Theory of Higher Education. The Journal of Higher Education, 41(2), 98-115. https://doi.org/10.2307/1977419

Kate Ashcroft and Philip Rayner-Article published on $1^{\text {st }}$ August 2011-An Analysis of the Strengths and Weaknesses of Ethiopian Higher Education in world education news+ reviews (WENR Nov/Dec2002: Intensified Security Measures Leave many International Students Stranded).

Kem Saichaie, \& Christopher C., Morphew. (2014). What College and University Websites Reveal About the Purposes of Higher Education. The Journal of Higher Education, 85(4), 499-530. https://doi.org/10.1080/00221546.2014.11777338

M. B. Paulsen. (2013). Higher Education: Handbook of Theory and Research, 1 Higher Education: Handbook of Theory and Research 28, https://doi.org/10.1007/978-94-007-5836-0

Michael K. McClendon. (2003). State Governance Reform of Higher Education: Patterns, Trends, and Theories of the Public Policy Process Vanderbilt University. Handbook of Theory and Research for Higher Education, 18(2), 86. https://doi.org/10.1007/978-94-010-0137-3_2.

Mirfa Manzoor., Walayat Hussain., Aftab Ahmed., \& Mohammad Javid Iqbal. (2012). The Importance of Higher Education Websites and its Usability. International Journal of Basic and Applied Sciences, 1(2). https://doi.org/10.14419/ijbas.v1i2.73

Navin Singh, \& Rosemary Papa. (2010). The Impacts of Globalization in Higher Education.International Journal of Educational Leadership Preparation,5(2).

Olga Viberg, \& Åke Grönlund. (2013). Cross Cultural analysis of users attitude toward the use of mobile devices in second and foreign Language learning in higher education. Computer and Education Journal. https://doi.org/10.1016/j.compedu.2013.07.014

Paul R. Pintrich, \& Akane Zusho. (2002). Student Motivation and Self-Regulated Learning in the College Classroom, The University of Michigan. Handbook of Theory and Research for Higher Education, 74 (XVII), 74. https://doi.org/10.1007/978-94-010-0245-5_2

PD Umbach, MR Wawrzynski. (2005). Faculty do matter: The role of college faculty in student learning and engagement. Research in Higher education,46,153-184.https://doi.org/10.1007/s11162-004-1598-1

Pierre Bourdieu Erin, \& McNamara Horvat. (2001). Understanding Equity and Access in Higher Education, Temple University. Handbook of Theory and Research for Higher Education, 6, 46.

Sílvia Melo.Pfeifer, \& Patchareerat Yanaprasart. (2019). Introduction: plurilingual expatriate teachers in higher education. European Journal of Higher Education, 244-251.https://doi.org/10.1080/21568235.2019.1597748

Stephen Wilkins, \& Selina Neri. (2018). Managing Faculty in Transnational Higher Education: Expatriate Academics at International Branch Campuses. Journal of Studies in International Education (JSIE), 23(4), 451-472. https://doi.org/10.1177/1028315318814200

Study International staff, Uniquest (UQ), \& Pie News. (2019). Just how important is a university website, Jennifer Parsons, Uniquest's Director of Marketing, and Insights.

Tertiary Education in the 21st Century. (2001). Challenges and Opportunities Jamil Salmi1 World Bank, United States. Journal of the programme on institutional management in higher education, 13(2), 104.

The Weekly Times-Ethiopian Export Institute. 
Viberg, Olga, \& Grönlund, Åke. (2013). Cross-cultural analysis of users' attitudes toward the use of mobile devices in second and foreign language learning in higher education. A case from Sweden and China, 69, 169-180. https://doi.org/10.1016/j.compedu.2013.07.014

What are $21^{\text {st }}$ century skills posted a blog by Bri Stauffer on March-19 2020 in applied educational systems. https://www.aeseducation.com/blog/what-are-21st-century-skills.

Wondwosen Tamrat, \& Damtew Teferra. Internationalization of Ethiopian Higher Education Institutions: Manifestations of a Nascent System-doi.org/10.1177-https://journals.sagepub.com

World Bank, CIA World Fact-book.

Y.G, M. Lulat. (2003). Confronting the Burden of the Past: The Historical Antecedents of the Present Predicament of African Universities, State University of New York at Buffalo. Handbook of Theory and Research for Higher Education, 18(11), 72.https://doi.org/10.1007/978-94-010-0137-3_11

Yan Yan Lam. (2010). Impact of Globalization on Higher Education: An Empirical Study of Education Policy \& Planning of Design Education in Hong Kong. 3, 4. www.ccsenet.org/ies International Education Studies. https://doi.org/10.5539/ies.v3n4p73

\section{Copyrights}

Copyright for this article is retained by the author(s), with first publication rights granted to the journal.

This is an open-access article distributed under the terms and conditions of the Creative Commons Attribution license (http://creativecommons.org/licenses/by/4.0/). 